Original Research Paper

\title{
The Integration of Good Governance in Effectiveness of Regional Autonomy Implementation
}

\author{
Kiagus Muhammad Sobri \\ Faculty of Social and Political Studies, University of Sriwijaya, Indonesia
}

Article history

Received: 21-09-2016

Revised: 10-01-2017

Accepted: 11-01-2017

Email: sobriunsri@gmail.com

\begin{abstract}
The principle of autonomy is generally intended to accelerate the advancement and bring equal prosperity to all Indonesians in accordance with the needs and capabilities of each region. This advancement and prosperities were a result of determination and the decision-making as the local government authorities, which are considered to be most familiar with the condition of its own local societies and regions. This article discusses the good governance and its role in regional autonomy as well as its correlation with other stakeholder's good governance. What is the role of local government? What is the action that should be taken by local governments to address the new role? And what is the relationship between the local government and other stakeholders' good governance? The policy of decentralization and local autonomy are generally believed to be able to provide positive benefits in the realization of the goal namely improving the well-being and service to the community as well as economic empowerment of the region. Government decentralization is believed to ensure an effective accomplishment of aspirations and the needs of local communities for centralized designs community programs.
\end{abstract}

Keywords: Societies Aspirations, Effectiveness, Good Governance, Peace and Regional Autonomy

\section{Introduction}

The attention towards public services efficiencies must be a main priority for the government as this matter has caused problems in the community, as stated in Wasistiono (2001), that there are several reasons why the government's attention to the importance of public service management is still relatively limited. These reasons, among others are (i) Government institution generally conducted monopoly-form activities until there is no competition in it, whereas without the competition, there is no efficiency and quality improvement, (ii) In carrying out its activities, government officials rely on the authority of market power or consumer needs (iii) There is no accountability of downwards vertical, sideways or even upwards. This is because there is no nationally standardized instrument to measure the performance of each government official based on generally accepted standards, (iv) the authorities of government officials often get caught up in "ethics" view which prioritizes the views and their own desires, (v) Awareness of community members of their rights and obligations as citizens and as consumers are still relatively low, so they tend to accept blindly the services provided by government agencies. Moreover, when the service provided is free of charge.

With the inherent limitations in the public services implementation, hence the Government implements the Act No. 22, Year 1999 and revised to be the Act No. 32 of 2004, which seeks to update the public service in the form of authority decentralization to the local governments. This is due to the fact that local government is a government organizational unit closest to the people, hence it is considered to be most capable in translating the public demands, interests and aspirations the need to be accomplished or served by the regional government. Thus, when there are regional issues or problems that need to be handled by the central government, the maintenance of public service will be ineffective. Furthermore, there are also problem differences experienced in different as well as the aspect of demands, interests and aspirations. Therefore, in the Act No. 32 of Year 2004 on General Explanation described the giving of broad autonomy to the region aimed at accelerating the realization of public welfare through the improvement of service, empowerment and community participation (Bevir, 2009; Brinkerhoff and Goldsmith, 2005). 
Past empirical evidence suggest that the most efficient public service should be organized by the areas with minimum geographical control (minimal state), because local government is highly considerate on the community needs, the decision by local government is very responsive to the needs of society, which leads to the efficiencies by local authorities in the distribution of public funds (Padila, 2003). In addition, the competition between regions in giving their best service to the local communities will encourage the local governments to increase their innovation (Sidik, 2004).

\section{Research Objectives}

The current study aims at reviewing the concept of good governance and its role in regional autonomy as well as its correlation with other stakeholder's good governance.

\section{Methodology}

This paper is based on government official documents, legal acts, past empirical studies and evidences. It was prepared using critical review technique where all documents have been reviewed by focusing on the conceptual definition and debates surrounding the concept. Legal documents reviewed including the Indonesian Act No. 22, 1999, the revised Indonesian Act No. 32, 2004 and Law No. 33 (2004).

\section{Operational Definitions}

Good Governance: In the management of the regional autonomy policy, the most important vision that must be employed by the local government is promoting the implementation of the concept of good governance comprehensively and factual (Khoirudin, 2005). Why such meaningful good governance is so important for the implementation of regional autonomy? This is not other than the actualization of good governance promising clean government which is free of corruption, transparent, accountable, effective, efficient and promoting the public participation and private sector partnerships in developing the regions (Hendriks, 2014; Graaf and Asperen, 2016). Good Governance as a model for good government management which is believed to be a system that can be applied to local governments in achieving successful implementation of regional autonomy. However, on the other hand, the relationship map between the government and other good governance stakeholders which is required by good governance remains unclear. There is no surprise that the implementation of good governance in some areas is still hobbled. There is a tendency where the community enforces their claim to be given maximum services without considering the capability of local authorities. In fact there are some NGOs who claim to be the agents of change sometimes get stuck with just the effort in 'criticizing' local governments actions in governance without a clear direction which tend in worsening the conflict.
Effectiveness: Government effectiveness is determined by its ability to provide public services through open competition. To achieve effective governance, the strategies offered by World Bank are: openness and transparency, citizen participation in public affairs and closer service to the community.

Regional autonomy: Autonomy comes from the Latin word autor which means "own" and nomos "manage and organized". Definition of autonomy is closely related to the notion of centralization and decentralization of power. Centralization is the country decisional pattern in concentrating all political, economic and social in central governmental. Decentralization is the devolution of government authority from the central government to autonomous regions to organize and manages their own governmental affairs (Yep, 2010; Rondinelli and Cheema, 1983). The implementation of regional autonomy is a manifestation of democracy in local government which means that local communities are involved in the construction of policy for regional administration (Dehaene, 2005). Maintenance of local government oriented on political, economic, socialcultural and regional area aspects will establish the realistic and effective mechanisms of local governance. Therefore the application of the principles of autonomy in general will accelerate the progress and increase the welfare equitably to all in accordance with the needs and capabilities of each region.

\section{Democracy, Independencies and Participation}

The independence of a region, in a political sense, one of which can be measured by the degree of freedom by the area in taking the initiative for making important decisions on various issues (economic and political) faced, without pestered by or approval request from the central government (Khoirudin, 2005). Therefore, regional autonomy demands a planning model that is not only comprehensive but also more responsive for the people. Various social elements in communities such as universities (public and private) in the district and the various mediating structures in the societies can play a vital role in helping the government and local communities to raise the capacity of local initiatives, especially in preparing the necessary inputs for the process of policy formulation and the planning for region development.

The authority held by the autonomous region is also real in the sense that it should be based on the necessary statement as well as grow, live and thrive in the area. In other words a real autonomous authority is the authority that grows from the interests and aspirations of the local community, not solely established based on the bureaucracy demand or related regions (Hildreth and Bailey, 2014). Because if the establishment of the regional authority autonomy is not implemented based on the interests and aspirations of local people hence it contravenes the fact to be a responsible autonomy. In 
this case, the district is responsible for the development of improved services and better social welfare, development of democracy, equality as well as maintaining the harmonious relations between the center and regions and between regions in order to maintain the integrity of the countries in the Republic of Indonesia.

With the policy of decentralization and regional autonomy, as well as role and community proactive in programs to improve welfare and the elimination of poverty is easier to be established, because closer and open access to the policies and programs under the authority of the local government administration. With the decentralization of authority and autonomy given to the regions, people have wider opportunities to plan, implement and control the development of the region and have a better commitment to the change social, economic and political attitudes and behaviors towards the expected direction. With a very diverse community conditions (as in Indonesia) the decentralization policy will be able to expand the coverage and pro-active participation of diverse social groups in accordance with their aspirations and their each socio-cultural background. According to Gany (2001), the increment of society role accompanied by a shift in the government's previous roles include three things, namely the regulation and control, community service, the changing agents, towards an empowerment and control. This shows that the regional development should be done based on the importance of society as a whole and is not an intervention that is a hazard towards the society.

Approach, Principles and Components of Good Governance: Accountability, Participation and Partnership

The term of governance is often defined as administration and regularly reviewed as well as analyzed. Earlier, this term is widely introduced by institutions donors in the form of technical assistance and international cooperation in developing countries. World Bank publication in 1992 on governance and development, has introduced the concept of good governance (De Graaf et al., 2011; Roberts et al., 2007; Effendi, 2005). It can be caused by the power of the World Bank in 'pressing' the lending countries to accept a variety of programs offered. For example, structural adjustment programs offered by the World Bank are a model for problems solution in developing countries which emphasis on the issue of governance and institutional building. From the World Bank perspective, the government's role should be reduced as much as possible. Government effectiveness is determined by its ability to provide public services through open competition. To achieve effective governance, the strategies offered by World Bank are: Openness and transparency, citizen participation in public affairs and closer service to the community.
Despite good governance is often referred to various events and situations by various groups, the notion about good governance can be differed from one another (Graaf and Asperen, 2016). There are some people define good governance as the performance of an institution, such as the performance of the government of a country, company or community organizations which meet the specific prerequisites. There are also some people that define good governance as a concrete translation of democracy with necessitates the presence of civic culture as a pillar of sustainability for democracy itself. In short, good governance is generally interpreted as a fine maintenance and administering. The word "good" here is defined as following specific rules in suitability with the basic principles of good governance. Good governance construct the three pillars of strength which interact with each other, namely between the state (government), private sector and civil society. Thus the integration of good governance will have an influent in the changing of the role of government in response towards public issues. This time the good governance programs will focus on the need to change the 'government face' in becoming more responsive to the public needs.

There are three components/domains involved in good governance, the government (state), private sector and the society to interact and perform their respective functions (Effendi, 2005). The function of government institutions is to create economic accountability, conducive politic and laws because other than the role of government as regulator, it is also expected to play more role as a facilitator in allowing the public to actively participate independently as socio-economic practitioners. The private sector is function to create jobs and income, improving the people's living standards, maintains and improves the quality of the life as well as transfer science and technology to the society. While people play a positive role in social interaction, economic and political, including inviting the groups in society to participate in activities economy, social and political.

Good governance paradigm emphasizes on the importance of parallels in the relationship between government institutions, private and public. The three relationships should be in an equal position and mutual control (check and balance) to avoid domination or exploitation by one component to the other components. In the implementation of good governance, public sector or government is no longer dominant, but society and the private sector also plays a role in governance. Thus there is a synergistic and constructive relationship between government, the private sector and the public. Therefore, in this process, partnership mechanisms become important so that the established relationship will be stronger in the good governance implementation frame (Ajrullah, 2010). The accountability concept actually has long been known in governance or in public organizations. The concept of democracy country which 
comprises of citizen participation, public control towards the government, the responsiveness of government, is in line with the concept of bureaucratic accountability. In a democratic world, the state and local authorities were selected by the public and therefore they must be responsible or accountable to the public. When government accountability to the public is low, it may result in a reduction or even loss of government legitimacy and ultimately will create a governance crisis. Accountability will established and thrive in a democratic and transparent situation as well as with the presence of expression liberty. Thus, in the authorities' state, private accountability is difficult to be conducted as there are neither freedoms nor transparency.

Maintenance of good governance will have an influent on the changing of the government role in responding to the public issues. This time, good governance programs will focus on the need to 'government face' in' becoming more responsive towards public needs. In the perspective of regional development policy, the definition of public participation in the development process here is strictly emphasized that people should be involved in local decision making, rather than limited to hearing or consultation merely. This is what meant by Charles Lindbloom as Partisan Mutual Adjustment (PMA), which is the adjustment of policy view to the reality as well as in the negotiation process between the interests of the stakeholders policies. Or, in a more practical level, what are is by Bloomquist as advocacy coalition framework (ACF) (Dolan, 2003. Good governance requires the government to widely open the opportunities for the private sector to play a role in development and community service. In order to improve the development and performance of services to the public, government officials must improve the competitiveness of the private sector. Partnership is the principal form of mutual relations between government, business and society. Based on the real contribution of the business world and society towards the strategic developmental and governance goals can be identified as participation patterns and partnership in several levels and units.

The interaction between government and the private sector are often wrapped in the framework of the partnership, especially in fulfilling the needs of the public, public services and public goods (Marwel, 2015; Ajrullah, 2010). Along with the established interaction built on good governance, the basic idea of partnership appears to create a practical framework for effective and efficient between the government and the private sectors in order to strengthen and identify problems in development. As observed from the definitions and principles to be developed in good governance, there is no doubt that in implementing good governance, it is necessary to redefine the functions of government. However, the role of other stakeholders, such as the private sector and the public also needs to be clarified. This needs to be done considering that good governance, should be understood as a process rather than as a structure or a particular institution which is not only requires clear attitude and role of government alone. The roles of other stakeholder's governance also need to be clarified, especially when there is interaction between them. This is important considering the concept of good governance can only be developed if the performance of all stakeholders in the implementation of the government and the government plays a role as a facilitator, partner, or a catalyst.

\section{Evidences of Good Governance Implementation}

\section{The Government Side: Accountability}

Provision of public services which is uniform and quality is the governmental task including the local government, because the equality and quality of service is formulated as a service which are fast, inexpensive and fair. It is also one of the indicators of quality assessment for the administration in carrying out its duties and functions (Bordogna and Neri, 2014). Hence, the public administration or the government is valued on how far it complies with the demands, needs and the society expectations. The regional communities are highly expected to get good service from the local government officials professionally in accordance with their respective fields. Only if the authorities in the area have a high awareness institutionally, they are considered as the people servants. It is questionable considering that both central and local levels government officials before have a single loyalty to their superiors or fellow ruling elite towards the society, besides the officials often act as autonomous authorities which have the right to determine the fate of society.

Local government as a stakeholder and public servants, should not just neutral toward political parties and particular groups, but also responsible for their attitude, behavior and actions towards the public (citizens) in the framework of the duties, functions and the authority given to them. This is because the citizens, apart from holding the highest sovereignty in the country, they are also the owner of the country's wealth, the state/government's government sources of income, authority, power and so forth. Therefore it is logical, while power holders used the power and financial resources that come from the people, hence they must be accountable to the public.

The size of regional production/expenditure will indicate the level of financial accountability in a particular area. Production/Expenditure according to Law No. 33 of 2004 is the obligation of local governments that are recognized as a reduction of the state finances value, which consist of 
Administrative/Production Routine expenses and Capital/Production Development expenses. Even production routine (Administrative Expenditure) consists of Official Expenditures, Expenditures of goods, Good and Service Maintenance expenditures, Travel Expenses and others expenses. The Development Expenditures (Capex) comprises the capital expenditures consisting of 22 developmental sectors. The larger the region expenditures used for capital expenditure/development, the greater level of accountability for the benefit of people's welfare. However, although under Law No. 32 In 2004, the local government has been given full discretionary authority in using the funds transferred from the central government, the local governments have not been using it to conduct activities aimed at improving the welfare and community services through development programs. The report by the ASIAN Development Bank (2002) revealed that "local governments have spent more than $50 \%$ of total expenditure on salaries and only a portion in the real value of development production".

Studies conducted by the Institute of Public Administration towards regarding the implementation of public service accountability found that the local government reformed the bureaucracy in efficient financial management by discarding ineffective routine. Financial management is done by applying a system of Public Service Agency (PBA) microfinance, where there is program to transfer management through the formation of Sregan District Region Administration Developmental Institution, cooperation and business groups that are not bankable in order to grow. Based on these conducted efforts, hence Stragen district local government is appointed by Institute of Public Administration as regional government with Best Practice award (Sanusi, 2009). People deserve the best service from the local government officials. Best service can only be provided by people who are professional and well trained in the field. The spirit of autonomy if not well imbued will foster the excessive regionalism spirit.

\section{The Society Side: Participation}

Society as a forerunner of the government (because there would be no government without people) actually is the most important party with the application of the autonomy principles. At the lowest level, autonomy in term of individuals (elements forming the community) as the existence of freedom which is embodied in a human being, as one of the most precious gift of the Creator. Freedom is what allows individuals to be autonomous, so that they can actualize their best potential within themselves optimally. These autonomous individuals will then formed autonomous societies. A society that is autonomous should be capable in expressing their interest and have the room of opportunity in realization of that desire (Camus, 2009). In the 'development language', society that aware and capable in expressing their needs and accomplishing it, is known as empowered society. Thus, the society will be nonempowered when they do not have the capabilities and such opportunities.

When the society is 'empowered' then they will realize that they have the huge 'power' to determine various administration programs in their regions. The programs will be directed for the benefit of society as a whole, with regard to the needs, desires and capabilities of the region. 'Empowered' society will have high bargaining power towards the executive or legislative branches. They realize that the existence of legislators in that place of honor (parliament) is the process of developing the mandate from tem (community). So that at any time, the trust, is necessary to be taken from the legislators shoulder through specific mechanisms related to political parties. Similarly, if government officials cannot provide good service, then the public is entitled to disregard the service through their representatives in Parliament. So that the blessings from empowered society including having and allowed the freedom to achieve their interest in increasing the life quality in accordance to the need and the community abilities.

However, in fact, a community which is called 'local communities', majority of them live in rural life away from the hustle and bustle of the decision making progress towards the programs related to the needs and the desires of the community. They have the tendencies to ignore the actions conducted by the elites of society who usually live in urban areas. All they required is only the smoothness in the conductance of various daily life activities, without having to know the process that led to the creation of the 'smoothness' in the progress. Given this fact, the one who plays a huge role in determining their lives and enliven the stage of policies determination are actually the elites of society. It is still a blessing if the elites are really fighting for the interests of society. But it would be a catastrophe when 'society' is only used as merchandise used for personal or group benefits of the elites in the society.

One of the pillars of Bantul district success until appointed by the Institute of Public Administration as best practice, in improving the effectiveness of the governance task is by developing cohesiveness between the government and the public (societal cohesiveness) (Sanusi, 2009). In an effort to absorb the society aspirations and to find out the actual problems that need prompt solution, regent communication is conducted with all level of society, including through open house, face to face in the countryside, in touch with community leaders, a dialogue through the media and others. Through the relationship forum, the Government of Bantul Regency with all the staffs are always opens to 
suggestions as well as criticism from all parties both directly and indirectly.

\section{The Private Sector Side: Partnership}

Ideally, all the public needs and public service should be developed by the government and citizens should not be burdened with the cost of fulfilling the needs of the public. However, there is a dilemma between meeting the public needs and the needs for urbanization to accelerate economic development with limited government budget to finance the fulfillment of those needs. In addition, in order to face the changes in the environment that is increasingly dynamic and rapid, the government as state officials are required to conduct internal transformation to make it more adaptable to the needs of the public and stakeholders to continue to promote the elements of good governance, namely accountability, transparency and professionalism but on the other hand the government is still facing the problem of the limited resources availabilities. In addressing this dilemma, the role of the private sector is necessary through partnership pattern that can be encouraged through incentives, regulations and other facilities (Hahn and Pinks, 2014).

Government partnerships with the private sector can open up innovation and technology transfer in the area and this can be used as a reference for other regions by taking into account the characteristics of each area. Some of the benefits to be gained from the practice of this partnership are the establishment of some facilities and infrastructures which are required in public services that cannot be met by the government. In this case, the main target is the community, which the partnership should be able to bring benefits to society. Another benefit includes that partnerships can be used as a means of participation and develop the private sector in regional development, as an effort to increase the regional economy, open up opportunities for employment, as a medium of learning and technology transfer for the district as well as the means to increase local revenue (Latheef, 2002).

Within the framework of good governance involving the private sector in the governance process, there are a variety of partnership models that can be applied and developed. The parties involved in a partnership are highly dependent on the background and purpose of the partnership establishment. A partnership in the process of good governance can involve two sectors engagement which are the government and the private sector. Ideally, the government and private sector partnerships can be seen as the authority of assets ownership is still owned by the government, while in privatization cooperation, the assets will belong to the private sector. Other forms of partnership also including Private Sector Participation (PSP), Public Private Partnership (PPP) and PublicPrivate-Community Partnership (PPCP).

PSP is a type of partnership that is generally not capital intensive, where the private sector do the procurement and operation of infrastructure while the Government as a provider of infrastructure in accordance with policy. In this case the Government remains as asset owners and controllers in implementing the cooperation. Public Private Partnership (PPP) is a partnership of Government and private enterprises involving large investment/capital intensive which the private sector financing, build and manage the infrastructure and facilities, while the government as a partner who handles the setting of service, in this case remains as the owner of the assets and controlling the implementation of the cooperation (Barber, 2013; Katz and Bradley, 2013). Some of the cities in Indonesia have the tendency of limited partnership which only involving goods and services. There are no partnerships entered the realm of administrative services. This is due partly because some local officials still believe that the partnership with the private sector is only in the construction of the physical projects. Even some regions/cities have not made any partnership with the private sector in public services and regional development, namely Singkawang.

\section{Further Research and Recommendation}

Further study can be focusing on empirical evidence on how regional autonomy affected the community wellbeing. It can be carried out using survey research design in order to get the holistic view of this phenomenon. Detailed investigation can also be carried out using qualitative and ethnographic studies. By carrying out these studies, clear picture and useful evidence are able to be collected for further development.

\section{Concluding Remarks}

The decentralization policy and regional autonomy is generally believed to be able to provide a positive benefit for the realization of the goal in improving the welfare and service to the community and economic empowerment of the region, because the local government and community is the most familiar and acknowledge the social and economic condition in the regions. The success of decentralization and regional autonomy is determined by three domains. Firstly, the function of government institutions is to create the accountability of economy, politic and legal which are conducive because as government is also expected to act more as a facilitator in allowing the public to actively participate independently as socio-economic practitioners. Secondly, the participation of community in local development is something that cannot be disregarded. In the perspective of regional autonomy policy, which is defined as community participation here is strictly about community involvement in local decision making, rather than limited to hearing ideas or consultation purposes only and thirdly, a partnership 
between local governments and the private sector is one step that must be done to cover the limitations by the local government in providing public services and regional development. Limitations of local governments are not only in terms of funds, but also the limited number of personnel, ability/skill and experience. Hence to cover these limitations, the local government is able to allow the involvement of public sector as long as it is not contrary to the applicable law.

The mutual agreement concerning the governance arrangements by governments, societies and private sectors is what is meant by good governance. In order to establish the consensus, the country built a partnership mechanism to ensure that each party can determine the amount of participation taken in the interactions among the three. The observational approach, principles and objectives developed in good governance, there will be no doubt that the implementation of good governance in the regional autonomy needs to be done more effectively with the government functions facilitators, partners, or catalyst. It is also important that the role of other stakeholders, such as NGOs, private sector and the general public to be improved. It is necessary to be conducted as good governance, should be understood as a process rather than as a structure or a particular institution which not only requires a clear attitude and the role of government alone. The other roles of Stakeholder governance needs to be developed as well, especially when there are interactions between them. This is important given that the concept of good governance can only be developed if there are synergies between all stakeholders in the implementation of regional autonomy, so that they can work together in achieving the objectives of regional autonomy in order to improve the welfare and community services.

\section{Acknowledgement}

Special thanks and appreciation to the University of Sriwijaya for providing financial support and encouragement throughout the research conducted. Thanks to the research persons who have been activeley involved in the research.

\section{Funding Information}

The reseach is funded by The Faculty of Social and Political Studies, University of Sriwijaya, Indonesia.

\section{Ethics}

This paper fulfills the research ethics requirement as stipulated in the university regulations. Data provided in this paper was based on the recent references. There is no ethical issue.

\section{References}

Ajrullah, M., 2010. Governance and Partnership. www. million Ajrullah.com

Asian Development Bank. 2002. Annual Report 2002. Tien Wah Press (Pte) Ltd.

Barber, B., 2013. If Mayors Ruled the World: Dysfunctional Nations, Rising Cities. New Haven, CT: Yale University Press.

Bevir M. 2009. Key Concepts in Governance, Thousand Oaks, CA: Sage.

Bordogna, L. and S. Neri, 2014. Austerity policies, social dialogue and public services in Italian local government. Eur. Rev. Labour Res., 20: 357-371. DOI: $10.1177 / 1024258914535548$

Brinkerhoff, D.W. and A.A. Goldsmith, 2005. Institutional dualism and international development. A revisionist interpretation of good governance. Administrat. Society, 37: 199-224. DOI: $10.1177 / 0095399704272595$

Camus, L.V., 2009. The politics of the MST rural autonomous communities, the state and electoral politics. Latin American Perspectives, 136: 178-191. DOI: 10.1177 / 0094582 X09338608

De Graaf, G., V. Van Doeveren and A.M. Reynaers, 2011. Goedennl. wikipediabestuur waarden in de literatuur. Bestuurskunde, 2: 5-11.

Dehaene, M., 2005. A Conservative Framework for regional development patrick abercrombie's interwar experiments in regional planning. J. Plann. Educ. Res., 25: 131-148. DOI: 10.1177/0739456X04270369

Dolan, C., 2003. Economic policy and decision making at the intersection of domestic and international politics: The advocacy coalition framework and the national economic council. Policy Stud. J., 31: 209-236. DOI: 10.1111/1541-0072.00012

Effendi, S., 2005. Building a Culture of bureaucracy for Good Governance. Proceedings of the Workshop on Reforms, Organized by State Ministry of PAN (SMP' 05), Jakarta.

Gany, A.R., 2001. Abad menyogsong new approach based development of local self-reliance. Ujung Pandang, Hasauddin Press.

Graaf, G.D. and B.V. Asperen, 2016. The art of good governance: How images from the past provide inspiration for modern practice. Int. Rev. Admin. Sci. DOI: 10.1177/0020852316630392

Hahn, T. and J. Pinks, 2014. Private environmental governance through cross-sector partnerships: Tensions between competition and effectiveness. Organization Environ., 27: 140-160. DOI: 10.1177 / 1086026614530996

Hendriks, F., 2014. Understanding good urban governance: Essentials, shifts and values. Urban Affairs Rev., 50: 553-576. DOI: 10.1177 / 1078087413511782 
Hildreth, P. and D. Bailey, 2014. Place-based economic development strategy in England: Filling the missing space. Local Economy, 29: 4-5. DOI: $10.1177 / 0269094214535712$

Katz, B. and J. Bradley, 2013. The metropolitan revolution: How cities and metros are fixing our broken politics and fragile economy. Washington, DC: Brookings Institution Press.

Khoirudin, 2005. Skesa decentralization policy in Indonesia, format future towards independence autonomous region. Averroes Press Malang.

Latheef, M., 2002. Public-Private partnership for development in the maldives. South Asia Econ. J., 3: 241-252. DOI: $10.1177 / 139156140200300208$

Marwel, I.P., 2015. Rethinking the state in urban outcasts. Urban Studies, 53: 1-4. DOI: $10.1177 / 0042098015613256$

Padila, S., 2003. Critical Paradigm in Public Policy Studies. Student library, Yogyakarta.

Roberts, S.M., S. Wright and P. O'Neill, 2007. Good governance in the Pacific? Ambivalence Possibility Geoforum, 38: 867-984.

DOI: $10.1016 /$ j.geoforum.2007.04.003
Rondinelli, D. and O.G. Cheema, 1983. Implementing Decentralization Policies: An Introduction. In: Decentralization and Development: Policy Implementation in Developing Countries, Rondinelli, D. and G.S. Cheema (Eds.), Sage Publications, London.

Sanusi, A., 2009. Best practices, local government, institutional innovations, procedure, administrative and human resources development organization for cultural research centre institutional performance. Public Administration Institute, Jakarta.

Sidik, M., 2004. Indonesia fiscal decentralization policy and forward thinking. Universitas Brawijaya, Malang.

Wasistiono, 2001. Selected Capita for Local Government Management, Bandung, Alqapoint.

Yep, R., 2010. Understanding the autonomy of Hong Kong from historical and comparative perspectives. China Information, 24: 235-247.

DOI: $10.1177 / 0920203 \times 10380305$ 